\title{
Maintenance Plan for Performance Assessments and Composite Analyses of the Area 3 and Area 5 Radioactive Waste Management Sites at the Nevada Test Site
}

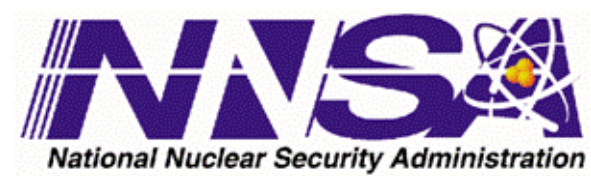




\section{DISCLAIMER}

Reference herein to any specific commercial product, process, or service by trade name, trademark, manufacturer, or otherwise does not necessarily constitute or imply its endorsement, recommendation, or favoring by the United States Government or any agency thereof or its contractors or subcontractors.

Available for sale to the public, in paper, from:

U.S. Department of Commerce

National Technical Information Service

5285 Port Royal Road

Springfield, VA 22161

Phone: (800) 553-6847

Fax: (703) 605-6900

E-mail: orders@ntis.gov

Online Ordering: http://www.ntis.gov/ordering.htm

Available electronically at http://www.osti.gov/bridge

Available for a processing fee to the U.S. Department of Energy and its contractors, in paper, from:

U.S. Department of Energy

Office of Scientific and Technical Information

P.O. Box 62

Oak Ridge, TN 37831-0062

Phone: (865) 576-8401

Fax: (865) 576-5728

E-mail: reports@adonis-osti.gov 


\title{
Maintenance Plan for Performance Assessments and Composite Analyses of the Area 3 and Area 5 Radioactive Waste Management Sites at the Nevada Test Site
}

\author{
Prepared for \\ U.S. Department of Energy \\ National Nuclear Security Administration \\ Nevada Site Office \\ under Contract Number \\ DE-AC52-06NA25946

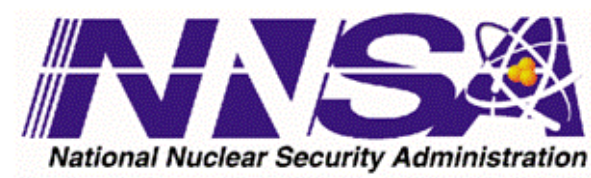

Prepared by

National Security Technologies LLC

January 2007 


\section{CONTENTS}

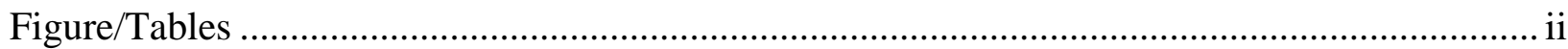

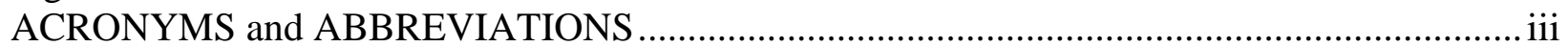

EXECUTIVE SUMMARY .......................................................................................... iv

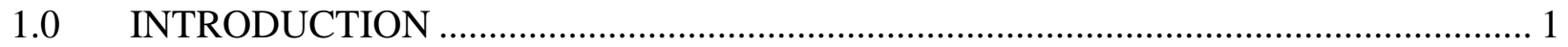

$1.1 \quad$ Purpose and Scope ................................................................................. 1

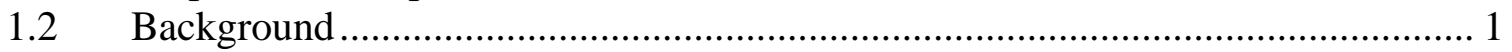

1.2.1 Tracking of Minor Issues ................................................................. 4

1.3 Organization............................................................................................. 4

2.0 MAINTENANCE PROGRAM ............................................................................ 6

2.1 Development of Assessment and Decision Analysis Tools................................ 6

2.2 Annual Review and Summary Report ....................................................... 9

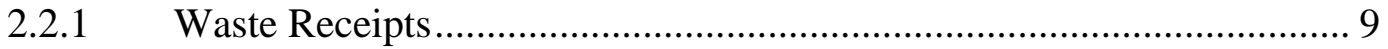

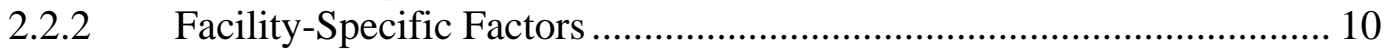

2.2.3 Sources of Residual Radioactive Material ........................................ 10

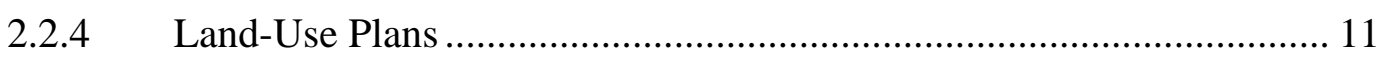

2.2.5 Monitoring and Research and Development..................................... 12

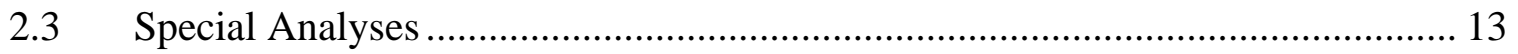

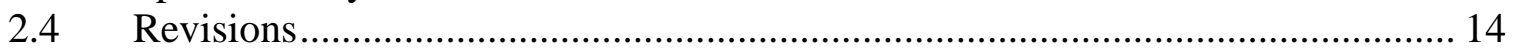

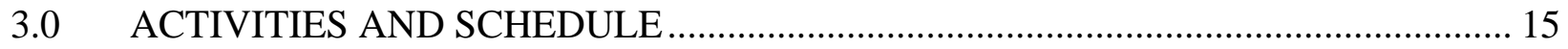

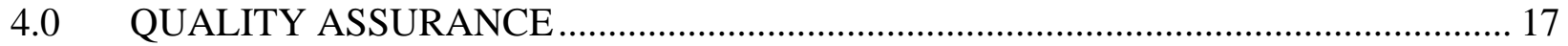

4.1 Analysis and Modeling Quality Assurance..................................................... 17

4.2 Quality Assurance for GoldSim Assessment Model Development...................... 17

4.3 Quality Assurance for GoldSim Inventory Model Development ......................... 18

4.4 Quality Assurance for GoldSim Model Applications....................................... 18

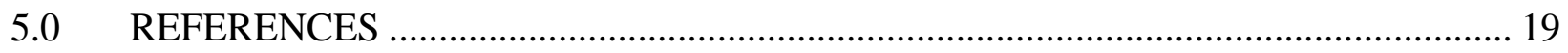

DISTRIBUTION 


\section{Figure/Tables}

Figure 1 Location Map of the Area 3 and Area 5 Radioactive Waste

Management Sites........................................................ 2

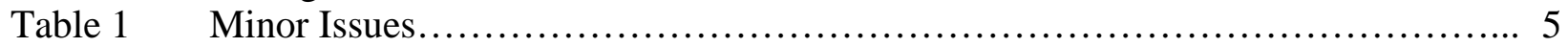

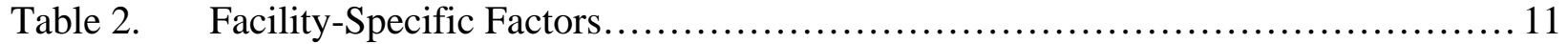

Table 3 The Schedule of Maintenance Activities..................................... 15 


\section{ACRONYMS and ABBREVIATIONS}

BN Bechtel Nevada

CA Composite Analysis

CADD Corrective Action Decision Document

CAU Corrective Action Unit

CD compact disc

CFR Code of Federal Regulations

DAS Disposal Authorization Statement

DOE U.S. Department of Energy

DOE/HQ U.S. Department of Energy Headquarters

ER Environmental Restoration

FFACO Federal Facility Agreement and Consent Order

FY fiscal year

GCD Greater Confinement Disposal

ICMP Integrated Closure and Monitoring Plan

LFRG Low-Level Waste Disposal Facility Federal Review Group

LLW low-level radioactive waste

M\&O management and operations

MOP member of the public

NSTec National Security Technologies, LLC

NNSA/NSO U.S. Department of Energy, National Nuclear Security Administration Nevada Site Office

NTS Nevada Test Site

NTSWAC Nevada Test Site Waste Acceptance Criteria

PA Performance Assessment

QA Quality Assurance

R\&D Research and Development

RWAP Radioactive Waste Acceptance Program

RWMS Radioactive Waste Management Site

TRU transuranic

UGTA Underground Test Area 


\section{EXECUTIVE SUMMARY}

U.S. Department of Energy (DOE) Manual M 435.1-1 requires that performance assessments (PAs) and composite analyses (CAs) for low-level waste (LLW) disposal facilities be maintained by the field offices. This plan describes the activities performed to maintain the PA and the CA for the Area 3 and Area 5 Radioactive Waste Management Sites (RWMSs) at the Nevada Test Site (NTS). This plan supersedes the Maintenance Plan for the Performance Assessments and Composite Analyses for the Area 3 and Area 5 Radioactive Waste Management Sites at the Nevada Test Site (DOE/NV/11718--491-REV 1, dated September 2002). The plan is based on U.S. Department of Energy (DOE) Order 435.1 (DOE, 1999a), DOE Manual M 435.1-1 (DOE, 1999b), the DOE M 435.1-1 Implementation Guide DOE G 435.1-1 (DOE, 1999c), and the Maintenance Guide for PAs and CAs (DOE, 1999d). The plan includes a current update on PA/CA documentation, a revised schedule, and a section on Quality Assurance.

Conditions for the continuing operation of a LLW facility are specified in the facility's Disposal Authorization Statement (DAS). The DAS is issued based on a review of the facility's PA, CA, maintenance plan, preliminary closure plan, and preliminary monitoring plan. The DAS specifies the limits and conditions on construction, design, operations, and closure of the lowlevel waste facility. Failure to obtain a DAS and failure to maintain the conditions of the DAS may result in shutdown of the disposal facility.

As stated in the Maintenance Guide (DOE, 1999d), the PA and the CA shall be maintained to evaluate changes that could affect the performance, design, and operating bases for the facility. Changes can occur in waste forms or containers, radionuclide inventories, facility design and operations, and closure concepts. Improved understanding of the performance of the waste disposal facility through monitoring and research may lead to changes to the conceptual models upon which the PA and CA are based. All these factors may alter the conclusions of the existing PA and CA. The goal of the maintenance program is to assure that the conclusions of the PAs and CAs remain current and consistent with the changes occurring, and are protective of the health and safety of the public.

The maintenance process consists of conducting research, field studies, and monitoring needed to address uncertainties or gaps in existing data, performing annual reviews of operating conditions, submitting annual summary reports to DOE Headquarters (DOE/HQ), carrying out special analyses, and revising the PAs and CAs, if necessary.

Management of uncertainty is an essential component of the maintenance program because the results of the original PAs and CAs are understood to be uncertain in the conceptual models; the mathematical models and their parameters; and the future state of the site, disposal facilities, and human activities. A determination of the continuing adequacy of the PA and CA is made on an annual basis. The annual reviews of the PAs include consideration of the current year's waste receipts, the current closure inventory estimate, current operational and facility-specific conditions, and results of monitoring and research and development (R\&D) activities. Likewise, results of ongoing $\mathrm{R} \& \mathrm{D}$, changes in land-use planning, new information on known sources of 
residual radioactive materials, and identification of new sources may warrant an evaluation to determine the impacts on the conclusions of the CA. The results of the annual reviews are documented in an annual summary report which includes a determination of the need to revise the PA or CA. PA and CA revisions during the operational phase will be made when judged necessary by the DOE, National Nuclear Security Administration Nevada Site Office (NNSA/NSO). The PA and CA will be updated to support final facility closure. As stated in the Maintenance Guide, additional iterations of the PA and CA shall be conducted as required by changing conditions during the post-closure period.

The following PA and CA maintenance program activities are included in the NNSA/NSO's Low-Level Waste Life Cycle Baseline (Bechtel Nevada [BN], 2002a):

- Development of assessment/decision tools

- Annual reviews

- Annual summary reporting

- PA/CA revisions

- Special analyses

- Support to the NTS Radioactive Waste Acceptance Program (RWAP)

- Maintenance plan revision

- Task supervision

Development of the assessment/decision analysis tools is a continuous process. Since 2002, NNSA/NSO has developed probabilistic PA/CA models for the Area 3 and Area 5 RWMSs using the GoldSim ${ }^{\circledR}$ probabilistic modeling platform. The PA/CA models are used to quantify uncertainty, guide uncertainty reduction, support PA/CA revisions, evaluate the impact of changes in the closure inventories, support the design of new disposal cells for special waste streams and closure covers, and support other management decisions regarding the efficient use of NTS disposal facilities. In addition, closure inventory models were developed in GoldSim for each facility to continuously track the waste disposals and update closure inventory estimates and uncertainties.

The reviews and the preparation of summary reports are annual activities. The first annual summary report for the Area 3 RWMS (including the results of the 2001 annual review) was submitted to DOE/HQ in March 2002 (BN, 2002b). Starting in fiscal year (FY) 2003, a single annual summary report has been issued covering the reviews of both the Area 3 and Area 5 RWMSs. No annual reviews or summary reports will take place in years that PA or CA revisions are made.

The decision to revise a PA or CA is made by NNSA/NSO based on the results of annual reviews and special analyses of proposed changes to site inventory, operating conditions, or closure plans. PA and CA revisions or addenda will be submitted to DOE/HQ for review and approval. An addendum to the Area 5 RWMS PA, addressing changes in the assessment model, closure inventory, and the reduction in the regulatory compliance period from 10,000 to 1,000 years, was published in 2006. The DOE/HQ reviewed and approved the Area 5 RWMS PA addendum, which has since been issued to the public as Addendum 2 (BN, 2006a). 
A revision of the Area 3 RWMS PA is scheduled for FY 2008. No other interim PA revisions are scheduled prior to the final PA and CA for each facility at closure. However, CA revisions are scheduled because the requirement for CA revisions has been specified in the respective DASs for each of the facilities. The first scheduled Area 5 RWMS CA revision will incorporate the results of the Frenchman Flat Corrective Action Unit (CAU) Corrective Action Decision Document (CADD), currently scheduled for completion in FY 2009. Therefore, revision of the Area 5 CA is scheduled for FY 2010. The revised Area 3 RWMS CA will incorporate the results from the Yucca Flat CAU CADD currently scheduled for completion in FY 2020. A revision of the Area 3 RWMS CA is scheduled for FY 2021.

Special analyses, including modeling and evaluations that directly or indirectly impact the results of the PAs and CAs, are scheduled annually. A special analysis is scheduled for FY 2007 to evaluate the potential for transuranic waste disposed in classified trench 4 (T04C) at the Area 5 RWMS to comply with Title 40 Code of Federal Regulations, Part 191. The support of the NTS RWAP, including the NTS Waste Acceptance Criteria, will be an ongoing activity during the operational life of each facility.

The maintenance plan will be updated, as needed, to reflect changes in activities and schedules and regulatory requirements. Task supervision, scheduled annually, includes continuous technical and administrative activities pertaining to the maintenance program execution. 


\section{$1.0 \quad$ INTRODUCTION}

\subsection{Purpose and Scope}

U.S. Department of Energy (DOE) Manual M 435.1-1 requires that performance assessments (PAs) and composite analyses (CAs) for low-level waste (LLW) disposal facilities be maintained by the field offices. This plan describes the activities to be performed to maintain the PA and CA for the Area 3 and Area 5 Radioactive Waste Management Sites (RWMSs) at the Nevada Test Site (NTS) (refer to Figure 1). This plan supersedes the Maintenance Plan for the Performance Assessments and Composite Analyses of the Area 3 and Area 5 Radioactive Waste Management Sites at the Nevada Test Site (DOE/NV 11718--491-REV 1, dated September 2002). The plan is based on DOE Order 435.1 (DOE, 1999a), DOE Manual M 435.1-1 (DOE, 1999b), the DOE Manual M 435.1-1 Implementation Guide (DOE G 435.1-1 [DOE, 1999c]), and the DOE PA/CA Maintenance Guide (DOE Order 435.1-3 [DOE, 1999d]). It is noted that the DOE's National Nuclear Security Administration Nevada Site Office (NNSA/NSO) issued the Radioactive Waste Management Manual (NV M 435.1-1) on August 29, 2000 (updated October 31, 2005), to implement the requirements of DOE Order 435.1 and DOE Manual M 435.1-1.

The Disposal Authorization Statement (DAS) for a DOE LLW facility specifies the conditions for operations based on the approved PA and CA, and requires that the facility implement a maintenance program. The goal of the maintenance program is to ensure that operations remain protective of the public in the future as conditions change. The maintenance process is an iterative one where changing conditions may result in a revision of the PA and CA, and the revised PA and CA may impose a different set of conditions for facility operation, closure, and post-closure.

The maintenance process consists of managing uncertainty, performing annual reviews, submitting annual summary reports to DOE Headquarters (DOE/HQ), performing special analyses, and revising the PAs and CAs, if necessary. Management of uncertainty is an essential component of the maintenance program because the results of the original PAs and CAs are uncertain in the conceptual models; the mathematical models and their parameters; and the future state of the lands, disposal facilities, and human activities. The annual reviews for the PAs include consideration of waste receipts, facility-specific operating conditions, results of monitoring, and results of research and development (R\&D) activities.

Likewise, the CAs are reviewed to determine the impacts of ongoing $R \& D$ results, changes in land-use planning, new information on known sources of residual radioactive materials, and identification of new sources.

\section{$1.2 \quad$ Background}

DASs for the Area 5 and Area 3 RWMSs were issued by DOE/HQ on December 5, 2000, and October 20, 1999, respectively. Documents supporting the DASs and those issued under the maintenance program to date are summarized below. 


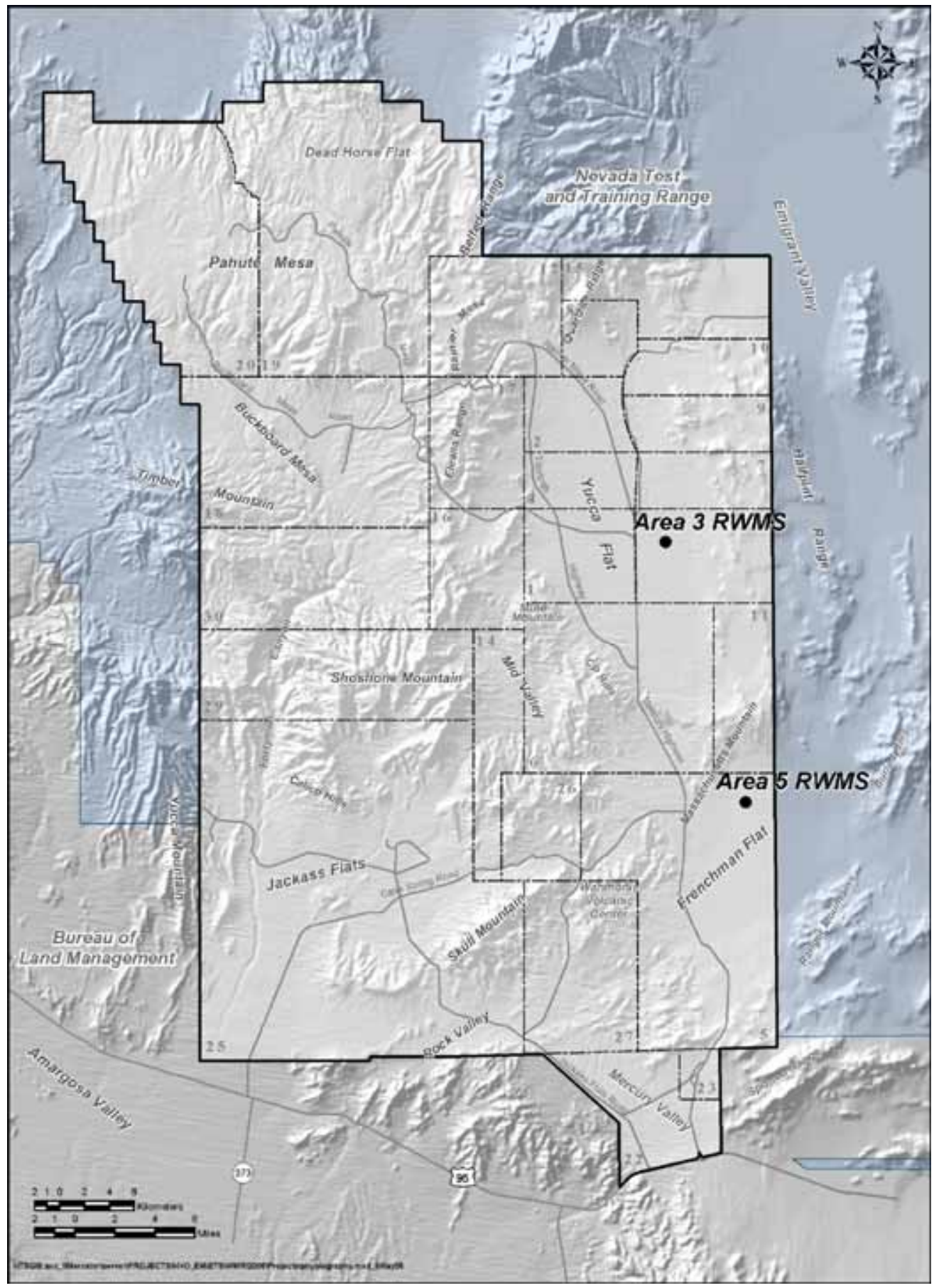

Figure 1

Location Map of the Area 3 and Area 5 Radioactive Waste Management Sites 
A PA was conducted for the Area 5 RWMS and submitted to DOE/HQ for review in July 1995 (Shott et al.,1995). After its review by the DOE PA Peer Review Panel, the Area 5 RWMS PA was accepted with conditions (DOE, 1996a). Subsequently, the document was revised, incorporating changes as directed by the reviewers, and published (Shott et al., 1998). A CA for the Area 5 RWMS was completed in February 2000 (Bechtel Nevada [BN], 2000). The DOE Low-Level Waste Disposal Facility Federal Review Group (LFRG) reviewed both the CA and the revised PA document in fiscal year (FY) 2000. Upon the LFRG's recommendation, DOE/HQ issued a conditional DAS for the Area 5 RWMS on December 5, 2000, and required that the specified conditions be addressed within one year of the DAS issuance. To resolve these conditions, NNSA/NSO submitted to the DOE/HQ in November 2001 two addendum reports (one for the PA and one for the CA) (BN, 2001a; 2001b). Both reports were approved in May 2002, with conditions met and issues closed. Other conditions remain in the DAS, including minor issues that are to be addressed as part of PA maintenance, and the condition that NNSA/NSO will incorporate in a future revision of the CA the dose from the Underground Test Areas (UGTAs) within Frenchman Flat.

A second addendum to the Area 5 PA was issued in 2005, which updates the deterministic PA model and parameters with a probabilistic GoldSim ${ }^{\circledR}$ model with probabilistic parameter distributions, updated closure inventory distributions, and includes a reduction in the regulatory compliance period from 10,000 years to 1,000 years. Addendum 2 to the Area 5 RWMS PA was approved by the LFRG without conditions and issued to the public in June 2006 (BN, 2006a).

A combined PA and CA document was prepared in 1997 for the Area 3 RWMS (Shott et al., 1997). The LFRG conducted a review of the document and recommended formal authorization for disposal operations with conditions. Following the LFRG's recommendation, DOE/HQ issued the DAS for the Area 3 RWMS on October 20, 1999. The DAS for the Area 3 RWMS identified six secondary PA issues, one primary and one secondary CA issue, and requested that NNSA/NSO resolve these specified issues and revise the PA and CA accordingly. The revised PA and CA document was submitted to DOE/HQ for review in FY 2001. On July 25, 2001, DOE/HQ informed NNSA/NSO that, while some conditions had been resolved, others remained, and that NNSA/NSO should provide appropriate documentation to close the outstanding conditions. In January 2002, NNSA/NSO provided DOE/HQ with a letter report addressing the outstanding conditions (BN, 2001c). In August 2002, DOE/HQ informed NNSA/NSO that all DAS conditions had been resolved and identified topics that should be addressed as part of the maintenance program. The Area 3 RWMS DAS calls for a future revision of the CA to incorporate the dose from the underground testing within Yucca Flat.

A PA for the transuranic (TRU) waste emplaced in four greater confinement disposal (GCD) boreholes at the Area 5 RWMS was prepared by Sandia National Laboratories (Cochran et al., 2001) to demonstrate consistency with the requirements of Title 40 Code of Federal Regulations (CFR) Part 191 (2006a). The GCD PA was reviewed by the LFRG in FY 2001, and conditionally accepted. NNSA/NSO does not plan to revise the GCD PA. Any needed changes in the GCD PA will be implemented through the maintenance program for the Area 5 RWMS. 
The first annual summary report for the Area 3 RWMS (including the results of the 2001 annual review) was submitted to DOE/HQ in March 2002 (BN, 2002b). Since 2003, a single annual summary report is being issued for both the Area 3 and Area 5 RWMSs. To date, annual review reports have been issued for 2002, 2003, 2004, and 2005 (BN, 2003; BN, 2004; BN, 2005a; BN, 2006b).

\subsubsection{Tracking of Minor Issues}

As stated in the DASs, NNSA/NSO will address all minor or secondary issues identified in the LFRG Review Reports for the Area 3 and Area 5 RWMS PAs and CAs as part of the maintenance program. The implementation of this plan will assure that these minor issues are addressed. Table 1 lists the issues that are being tracked and resolved through the maintenance program. The resolution pathway for each issue is included in the third column of Table 1.

\subsection{Organization}

Section 2.0 of this document presents the elements of the PA and CA Maintenance Plan for the Area 3 and Area 5 RWMSs at the NTS: the development of the maintenance tools, the annual reviews and summaries, special analyses, and revisions. Section 2.1 includes a summary of the development of the GoldSim PA/CA models for the Area 3 and Area 5 RWMSs. The annual reviews and summaries for the PA and CA including the discussions of the waste receipts, facility-specific factors, residual sources of radioactive materials at the NTS, land-use plans, and monitoring and R\&D results are given in Section 2.2. Section 2.3 discusses the special analyses; and Section 2.4 addresses the revisions.

Planned activities and their schedules are provided in Section 3.0. This revision of the plan also includes a new section on quality assurance, Section 4.0. 
Table 1

Minor Issues

\begin{tabular}{|c|c|c|}
\hline Identified Issues & $\begin{array}{l}\text { Source Document } \\
\text { For Issue }\end{array}$ & Resolution Pathway \\
\hline $\begin{array}{l}\text { The assurance requirements of } \\
\text { Title } 40 \text { CFR } 191 \text { must be met for } \\
\text { the GCD boreholes. }\end{array}$ & GCD PA & $\begin{array}{l}\text { The assurance requirements will be met at the } \\
\text { time of closure of the Area } 5 \text { RWMS, as stated } \\
\text { in the Integrated Closure and Monitoring Plan } \\
\text { for the Area } 3 \text { and Area } 5 \text { Radioactive Waste } \\
\text { Management Sites at the Nevada Test Site } \\
\text { (ICMP) (BN, 2005b). }\end{array}$ \\
\hline $\begin{array}{l}\text { Inconsistencies between } \\
\text { conceptual models for the Area } 5 \\
\text { RWMS PA and CA, the Area } 3 \\
\text { RWMS PA and CA, and the GCD } \\
\text { PA. }\end{array}$ & $\begin{array}{l}\text { Area } 5 \text { RWMS PA, } \\
\text { Area } 3 \text { RWMS } \\
\text { PA/CA, GCD PA }\end{array}$ & $\begin{array}{l}\text { The issue is being addressed in the } \\
\text { development of the Area } 3 \text { and Area } 5 \text { RWMS } \\
\text { GoldSim models; the progress of the work will } \\
\text { continue to be reported in the annual review } \\
\text { reports. }\end{array}$ \\
\hline $\begin{array}{l}\text { Conduct site monitoring and site } \\
\text { characterization studies as } \\
\text { required to increase confidence } \\
\text { in the results of the PAs. }\end{array}$ & $\begin{array}{l}\text { Area } 3 \text { RWMS } \\
\text { PA/CA }\end{array}$ & $\begin{array}{l}\text { Monitoring programs at both Area } 3 \text { and Area } 5 \\
\text { RWMSs are ongoing, and data are being } \\
\text { incorporated into the GoldSim PA models; } \\
\text { impact on the uncertainty and confidence in } \\
\text { results are presented in annual summary } \\
\text { reports. }\end{array}$ \\
\hline $\begin{array}{l}\text { The maintenance program must } \\
\text { include periodic assessment of } \\
\text { changes to potentially interacting } \\
\text { sources (UGTA, industrial sites) } \\
\text { and impacts on the CAs. }\end{array}$ & $\begin{array}{l}\text { Area } 5 \text { RWMS CA, } \\
\text { Area } 3 \text { RWMS } \\
\text { PA/CA }\end{array}$ & $\begin{array}{l}\text { Changes in potentially interacting sources will } \\
\text { be evaluated through the maintenance } \\
\text { program and results presented in the annual } \\
\text { summary reports. }\end{array}$ \\
\hline $\begin{array}{l}\text { The maintenance program must } \\
\text { include periodic assessment of } \\
\text { changes to land-use restrictions } \\
\text { and impacts on the CAs. }\end{array}$ & $\begin{array}{l}\text { Area } 5 \text { RWMS CA, } \\
\text { Area } 3 \text { RWMS } \\
\text { PA/CA }\end{array}$ & $\begin{array}{l}\text { Changes in land-use restrictions will be } \\
\text { reviewed through the maintenance program } \\
\text { and results presented in the annual summary } \\
\text { reports. }\end{array}$ \\
\hline $\begin{array}{l}\text { Monitoring systems need to be } \\
\text { deployed and data gathered and } \\
\text { evaluated to distinguish between } \\
\text { interacting sources at the Area } 3 \\
\text { RWMS. }\end{array}$ & $\begin{array}{l}\text { Area } 3 \text { RWMS } \\
\text { PA/CA }\end{array}$ & $\begin{array}{l}\text { The monitoring systems deployed at the } \\
\text { disposal facilities are described in the ICMP } \\
\text { (BN, 2005b); monitoring results will be } \\
\text { evaluated and presented in the annual } \\
\text { summary reports. }\end{array}$ \\
\hline
\end{tabular}




\subsection{MAINTENANCE PROGRAM}

The goals of the maintenance program are to ensure that the facilities are in compliance, quantify and reduce uncertainty, and use knowledge of uncertainty to guide decisions concerning management of the disposal facilities.

Serving the DOE complex effectively and efficiently, while keeping the Area 3 and Area 5 RWMSs in compliance, is an operating principle of the maintenance program at the NTS. The facilities continue to receive and dispose LLW from DOE operations and cleanup activities on the NTS, and from off-site generators across the DOE complex. The NTS LLW disposal sites, along with the Hanford site in Washington State, are designated by DOE/HQ as regional disposal centers (Federal Register, 2000), and serve the DOE complex through evaluation and acceptance of high-specific-activity LLW when possible.

The impact of uncertainty on the conclusions of the PA/CAs for the NTS facilities must be evaluated systematically during the operational period to aid the NNSA/NSO in the efficient management of their continuing disposal operations. Additionally, quantification of uncertainty provides information that can be used for more effective management of monitoring and closure programs.

To accomplish these goals, the PA maintenance program includes the following activities discussed in this section:

- Developing assessment and decision analysis tools

- Performing annual reviews and developing annual summary reports

- Performing special analyses

- $\quad$ Revising the PA and CA documents

\subsection{Development of Assessment and Decision Analysis Tools}

The NNSA/NSO initiated the conversion and integration of the approved PAs and CAs for the Area 3 and Area 5 RWMSs into a probabilistic modeling platform to increase programmatic efficiency, better assess uncertainty of the disposal systems, and facilitate decisions regarding closures. GoldSim probabilistic simulation software was selected for this purpose because it provides the required capability (Golder Associates, 2001). The primary strengths of GoldSim include the following:

- It was designed from inception as a fully probabilistic computer code.

- It is highly versatile for PA applications.

- The program contains modules designed for probabilistic modeling of the multiple components of a waste disposal system. 
- The GoldSim computer code has been used for multiple national and international PA studies, including the Total Systems PA for the Yucca Mountain Project (DOE, 2001).

- The computer code has been verified and documented (McGrath and Beckham, 2001).

The development of the model to date followed the following process:

- Incorporate the existing PA structure and input fixed-point (deterministic) parameters into the GoldSim probabilistic computer program.

- Benchmark the deterministic GoldSim model results against the results of the approved PAs using the PA performance objectives as the main basis for comparison. Document and compare model outputs at a sufficient level of detail to allow a reviewer to readily compare the model results and assess model equivalency.

- Retain the model framework and systematically convert deterministic parameter inputs for the PA model into probability distributions.

- Re-run the GoldSim model with probability distributions for input parameters. Compare the revised results with the deterministic data runs to calibrate differences in output between the probabilistic and deterministic data sets.

- Conduct sensitivity analysis of the model output from the revised probabilistic computer output to identify the input parameters that most significantly impact the output results. Use the results of sensitivity analysis to assess the value of revising the model structure, gathering additional information or refining parameter distributions, or both. Uncertainty and sensitivity analyses should be performed in tandem to assess uncertainty components that can be attributed to input parameters and to target future data collection on the most sensitive parameters.

- Use monitoring or characterization data, or both, to revise the input probability distributions in the GoldSim model using the new information. Continue iterative cycles of data assessment, model revision, and model runs to attempt to reduce uncertainty. The iterative cycles should not be open-ended. Completion of modeling efforts should be guided by the value of information studies using programmatic decision objectives established for the Area 3 and Area 5 RWMSs.

The structural framework of the Area 5 RWMS PA and CA was implemented initially in the GoldSim code and the code was run deterministically. Resulting model output closely matched the results of the Area 5 RWMS PA and CA and provides benchmark verification of the GoldSim model. 
After completion of benchmarking, a fully probabilistic GoldSim model was developed for the Area 5 RWMS PA and CA. Development of the probabilistic model focused initially on three topics. The first is reduction in the conservatism of the original PA and CA. Conservative deterministic input parameters in the PA models were translated to probability density functions that better represent the information state and uncertainty of the parameters. Conservative bounding assumptions in the model were replaced wherever possible with probability density functions. For example, the rate of upward liquid advection was bounded by assumption in the Area 5 RWMS PA. It was converted to a beta distribution in the probabilistic model using abstracted modeling results from soil physics calculations, numerical models of water balance through time that incorporate climate change, and the results of stable isotopic studies. The inadvertent human intrusion was assumed to occur in the Area 5 RWMS PA (probability of 1). It was treated as a probability density function in the revised probabilistic model using the results of a subject matter expert elicitation (Black et al., 2001).

The second topic is examination of the technical justifications and model translations for model components shown to be significant in sensitivity analysis completed for the original Area 5 RWMS PA and CA. The Area 5 RWMS PA showed through sensitivity analysis that biotic processes (plant-root uptake and animal and insect burrowing), inventory, and factors influencing radon flux were highly sensitive parameters. A revised biotic uptake model was developed and the results of this model were abstracted into the probabilistic model. Rates of upward liquid advection were reexamined and a revised beta distribution was developed for the probabilistic model. Inventory amounts for all radionuclides are treated as probability density functions in the revised probability model.

Finally, a technical concern for the Area 3 and Area 5 RWMSs PA and CAs is consistency between models including model assumptions and parameters. Multiple iterative changes in the successive facility PA and CA models were upgraded to the most recent state of knowledge in the probabilistic model. For example, the dose model in the probabilistic PA model was updated to the model parameters and model structure used in the Area 3 RWMS PA and CA. Model and parameter data for upward advection used in the Area 3 PA/CA and the GCD PA are now implemented consistently in the probabilistic model. The source-term model was not changed for the revised probabilistic model. For future model iterations, depending on results of sensitivity analysis, the probabilistic model will incorporate parameter and model structure for container degradation, source-term release by radionuclide, and full solubility limits.

The final stage of completion of the probabilistic model is implementation of a decision analysis structure and application of multiple approaches to sensitivity analysis using simulation results from the probabilistic model. The decision model incorporates multiple management options for institutional control, revision of waste concentration limits, closure, monitoring, and cost-benefit analysis.

The development of the Area 5 RWMS GoldSim model is in its final stage, the current model version being v3.11mod. This version of the model supported the development of the recent addendum to the Area 5 RWMA PA (BN, 2006a), and it is being used for waste stream evaluations in support of the RWAP. The cumulative effect of model improvements occurring between 
the $1998 \mathrm{PA}$ and the v3.11mod version was assessed by comparing the results of Area 5 RWMS v3.11mod GoldSim model to the results of the 1998 PA model (BN, 2006a). A sensitivity analysis has been performed for the model, reported in Addendum 2 to the Area 5 RWMS PA (BN, 2006a). The next version of the model is expected to be completed by the end of FY 2006. Once completed, it will include a CA component as well as a component to perform a Title 40 CFR 191 PA for TRU waste. In FY 2007, the model is expected to include decision analysis tools to support as low as reasonably achievable analysis.

Currently, the Area 3 RWMS GoldSim model is at Version 1.0, and is considered to be preliminary. By the end of FY 2006, the model will be completed with a CA component, and will be subjected to sensitivity analysis and verified for acceptance by National Security Technologies, LLC (NSTec). In FY 2007, the model is expected to include decision analysis tools to support as low as reasonably achievable analysis.

\subsection{Annual Review and Summary Report}

The objectives of annual reviews can be summarized as the following:

- Confirm the effectiveness of existing controls to ensure that PA and CA conclusions are valid.

- Consider expected future events in terms of their significance to disposal operations and the adequacy of the PA and CA.

- Review new information and determine its significance to the PA and CA through special analysis, if necessary.

- Identify R\&D needs that have been met during the past year, new needs that have arisen as a result of changes in actual or expected future conditions, and revised R\&D priorities.

The result of the review will be documented in a summary report that will include conclusions drawn from the review and discussions of relevant factors supporting the determination of the PA and CA adequacy and specific actions recommended to be taken as a result of the review. A single annual report will be prepared and submitted to NNSA/NSO, combining the PA and CA reviews for both the Area 3 and the Area 5 RWMSs.

\subsubsection{Waste Receipts}

The review of waste receipts consists of several activities:

- Updating closure inventory estimates annually.

- Adjusting inventories according to results of analysis of past waste receipts. 
- Adjusting inventories on the basis of improvements in waste characterization that enhance estimates of waste in place.

- Verifying or modifying waste projections based on best available data.

- Determining consistency of new waste forms with the Nevada Test Site Waste Acceptance Criteria (NTSWAC) (NNSA/NSO, 2006a)

- Identifying and evaluating new radionuclides not evaluated in the PAs.

GoldSim inventory models that were developed in 2005-2006 are used to track waste receipts and update the closure inventories for each facility, as outlined above. Inventory model results, which are transported into the GoldSim PA models, are the geometric mean and standard deviation of the inventory for all radionuclides that are evaluated in the PA models. Inventory estimates are revised annually and PA models are run to determine whether the continued adequacy of the PA can be assured. Such inventory changes may also lead to revision of the waste concentration limits for future disposals at the Area 3 and Area 5 disposal facilities.

\subsubsection{Facility-Specific Factors}

The facility-specific factors that will be considered in the annual reviews are summarized in Table 2. Any changes in these operational and design factors will be evaluated as to their impacts on the performance assessment adequacy.

\subsubsection{Sources of Residual Radioactive Material}

The dose received in the future by a member of the public (MOP) from exposure to contaminated sites at the NTS will depend on future land-use policies, remediation, and closure activities. All environmental restoration (ER) activities at the NTS (remediation and closure of historically contaminated sites) are the sources of residual radioactive materials considered in the CAs for the Area 3 and Area 5 RWMSs. Remediation of ER sites at the NTS takes place under the Federal Facility Agreement and Consent Order (FFACO) between the DOE, the state of Nevada, and the U.S. Department of Defense (FFACO, 1996). The FFACO defines a Resource Conservation and Recovery Act-like process for remediation and closure of these sites and requires state of Nevada review and approval of all corrective actions. The results of the restoration activities associated with the ER sites (including UGTA, Industrial, and Soil Sites) need to be reviewed annually and incorporated into the CA when significant changes occur.

The review will consider the following:

- Is each source considered in the CA still valid (i.e., have potential sources been eliminated because of changes in site plans)?

- Has new information become available concerning the radiological, chemical, and physical characteristics of the source?

- Have new sources been identified and characterized? 
Table 2

Facility-Specific Factors

\begin{tabular}{|c|c|c|}
\hline Category & Subject & $\begin{array}{r}\text { Factors } \\
\end{array}$ \\
\hline \multirow{4}{*}{ Operations } & Disposal Geometry & $\begin{array}{ll}\text { - } & \text { depth of trench } \\
\text { - } & \text { depth of waste profile } \\
\text { - } & \text { thickness of backfill/cover }\end{array}$ \\
\hline & $\begin{array}{l}\text { Waste Form and } \\
\text { Packaging }\end{array}$ & $\begin{array}{ll} & \text { special waste forms } \\
\text { - } & \text { containers } \\
\end{array}$ \\
\hline & $\begin{array}{l}\text { Waste Acceptance } \\
\text { Criteria }\end{array}$ & $\begin{array}{l}\text { - } \text { radionuclide limits } \\
\text { - reporting of PA-significant } \\
\text { radionuclides }\end{array}$ \\
\hline & Procedures and Systems & $\begin{array}{l}\text { - verification of waste characteristics } \\
\text { (e.g., the radionuclide content) }\end{array}$ \\
\hline \multirow{5}{*}{ Facility/Closure Design } & Disposal Technology & $\begin{array}{l}\text { - technologies being used or planned } \\
\text { vs. those analyzed in the PA }\end{array}$ \\
\hline & Engineered Barriers & $\begin{array}{l}\text { - engineered barriers employed vs. } \\
\text { those analyzed in the PA } \\
\text { P closure cover design consistent with } \\
\text { PA assumptions } \\
\text { threats to cover integrity and viability }\end{array}$ \\
\hline & Other Design Features & $\begin{array}{l}\text { - provisions for performance } \\
\text { monitoring }\end{array}$ \\
\hline & Structural Stability & $\begin{array}{l}\text { - operational controls to enhance } \\
\text { stability being employed } \\
\text { - unexpected subsidence }\end{array}$ \\
\hline & Future Land Use & $\begin{array}{l}\text { PA assumptions consistent with } \\
\text { future land use plans }\end{array}$ \\
\hline
\end{tabular}

The overall result of the review will be a determination of whether any changes are needed to ensure the continuing adequacy of the CAs with respect to radionuclide releases from sources of residual radioactive materials other than the RWMSs. The review will also identify data gaps and uncertainties associated with sources of residual radioactive material that should be addressed through R\&D.

\subsubsection{Land-Use Plans}

Future land use is another key element of the basis for estimating dose to a hypothetical future MOP, and changes in land use must be considered in annual determinations of the CA adequacy (DOE, 1999d). The review of land use is to be based on a review of documentation such as land-use plans or planning documents, National Environmental Policy Act documents (e.g., environmental assessments and environmental impact statements), long-term stewardship documents, surveys of land use (past, present, and projected) adjacent to the DOE site, and other relevant documents. The overall result of the review will be a determination of whether any changes are needed to ensure the continued adequacy of the CA with respect to land-use assumptions. 
The current and future land-use planning for the NTS is described in the Final Environmental Impact Statement for the Nevada Test Site and Offsite Locations in the State of Nevada (DOE, 1996b). This document is implemented through the Nevada Test Site Resource Management Plan (DOE, 1998). The Area 3 and Area 5 RWMSs are identified as Restricted Use Zones in institutionally controlled areas in the NNSA/NSO Local Directive NSO M 412.X-2 (NNSA/NSO, 2006b).

\subsubsection{Monitoring and Research and Development}

Results of both on-site and off-site R\&D activities will be reviewed as part of the maintenance process. The Maintenance Guide (DOE, 1999d) refers to a variety of data collection activities as R\&D activities, in addition to traditional R\&D activities. Off-site R\&D activities include those at the other DOE sites, the national laboratories, the Desert Research Institute, and academic institutions.

The review of monitoring and $\mathrm{R} \& \mathrm{D}$ results consists of the following activities:

- Comparing facility monitoring results to expected performance and determining consistency with conceptual model(s)

- Using monitoring results to assess parameter uncertainty and changes in the PA releases

- Evaluating R\&D results to determine impacts on PA results and conclusions and consistency with conceptual model(s)

- Determining if better methods or technologies are available

- Evaluating the results of special analyses

The review will determine if data collected during monitoring or R\&D activities support the disposal facility performance postulated in the PA, and if the conceptual models are still reasonable representations of the disposal facility. The review will also allow NNSA/NSO to identify data needs and uncertainties and update the status of R\&D needs accordingly.

The results of the monitoring activities identified in the monitoring plan for the Area 3 and Area 5 RWMSs, as well as the results of NTS-wide routine environmental monitoring and surveillance activities, will also be reviewed. Routine radiological environmental monitoring and environmental surveillance on and off the NTS are described in the Routine Radiological Environmental Monitoring Plan (BN, 1998), which integrates all previous monitoring efforts at the NTS, and addresses compliance with DOE Order 5400.1 (1990) and DOE Order 5400.5 (1993), applicable federal and state regulations, and stakeholder issues. 


\subsection{Special Analyses}

Special analyses are performed to evaluate the significance of new information or supplement the analyses performed in the original PAs and CAs. The results of a special analysis may be used to determine whether a PA or CA revision is needed. The following operational and natural changes at NTS disposal sites may necessitate a special analysis:

- Disposal of radionuclides not analyzed in the PA

- Disposal of waste streams not analyzed in the PA

- Changes in waste forms that could increase release rates for critical radionuclides

- Wastes that exceed the concentrations of significant radionuclides analyzed in the PA

- Wastes that cause the site to exceed the total inventory of significant radionuclides analyzed in the PA

- Changes in the disposal facility design or operations from those described in the PA

- Changes in the physical setting (changes due to climate change or catastrophic events and changes in plants or animal species, or both)

- Changes in the compliance period, the time of closures, the institutional control period from those described in the PA and CA

- Changes in future land-use and human activities from those described in the CA

Special analyses will be performed using the GoldSim assessment and decision models for the disposal facilities. The type of analyses to be performed will include the following:

- Evaluating the uncertainty in the estimated performance of the disposal sites for the multiple performance objectives of DOE Order 435.1

- Assessing reduction in model conservatism and the resulting reduction in uncertainty in the PAs and CAs

- The programmatic benefits of uncertainty reduction for the decision objectives of the disposal sites

- Testing and verifying the conceptual models of the geohydrological setting of the disposal systems (including testing of alternative conceptual models which are consistent with site characterization data) 
- Iteratively assessing the impacts of data gathered from site monitoring and additional site characterization studies on the PA and CA results

- Streamlining the monitoring program based on the results of sensitivity and uncertainty analysis of the results of probabilistic modeling of system performance

- Iteratively evaluating and refining waste concentration limits for the disposal sites

- Continuing evaluations on a case-by-case basis of the acceptability of new waste streams for disposal at the NTS facilities

- Applying the results of probabilistic modeling for refining and reducing the cost of strategies used for the monitoring program and to close disposal cells

- Using the results of iterative probabilistic modeling to establish decision objectives for transitioning the disposal sites to long-term stewardship

\subsection{Revisions}

At the discretion of the NNSA/NSO, PAs and CAs will be revised when changes in waste forms or containers, radionuclide inventories, facility design and operations, closure concepts, or new data or information about the natural setting of the site alter the conclusions or the conceptual model(s) of the existing PA and CA that are documented in the disposal facility DASs. A PA revision will include updated information (e.g., results from monitoring and R\&D), revised analyses, descriptions of new models, radionuclide inventories, or other items affecting the results. Likewise, a CA revision will include updated information (e.g., land-use plans; results from monitoring and R\&D), revised analyses, new models, changes in expected radionuclide inventories, or other items affecting the results.

The need for PA or CA revision will be determined by NNSA/NSO based on the results of annual reviews and special analyses. The form of a revision will be an addendum or revised PA/CA document. Report revisions will be submitted to DOE/HQ for review and approval. Revisions may also lead to revision of the DAS because facility operation parameters may change. At disposal facility closure, a final PA and CA will be prepared and submitted to $\mathrm{DOE} / \mathrm{HQ}$ for approval, together with the final monitoring and closure plans. 


\subsection{ACTIVITIES AND SCHEDULE}

The following PA and CA maintenance activities are included in NNSA/NSO's Low-Level Waste Life Cycle Baseline (BN, 2002a):

- Development of assessment and decision tools

- Annual reviews

- Annual summary reporting

- PA and CA revisions

- Special analyses

- Support to the NTS Radioactive Waste Acceptance Program (RWAP)

- Maintenance plan revision

- Task supervision

The schedule of activities is summarized in Table 3. Maintenance activities will continue throughout the operational life of each RWMS and beyond, as necessary. Decision to continue the PA activities during the post-closure period will be determined at facility closure.

Development of the assessment and decision tools, which is a continuous improvement process, is scheduled annually. Except for the PA/CA revisions and the maintenance plan revision, all PA activities are scheduled annually.

Table 3

Schedule of Maintenance Activities

\begin{tabular}{|l|l|}
\hline \multicolumn{1}{|c|}{ Activity } & \multicolumn{1}{c|}{ Frequency or Fiscal Year } \\
\hline Development of Assessment/Decision Tools & Annual \\
\hline Annual Reviews & Annual \\
\hline Annual Summary Reporting & Annual \\
\hline PA/CA Revisions & Area 3 RWMS PA - FY 2008 \\
& Area 5 RWMS CA - FY 2010 \\
& Area 3 RWMS CA - FY 2021 \\
& Final Area 3 RWMS PA/CA at closure \\
& Final Area 5 RWMS PA/CA at closure \\
\hline Special Analyses & Title 40 CFR 191 PA for TRU in trench T04C in \\
& FY 2007 \\
& Annual \\
\hline Support to NTS RWAP & Annual \\
\hline Maintenance Plan Revision & As needed \\
\hline Task Supervision & Annual \\
\hline
\end{tabular}


This plan schedules a PA revision for the Area 3 RWMS in FY 2008. A final PA and CA are scheduled for each facility at closure. The current closure dates are FY 2011 for the 92-acre lowlevel mixed waste management unit of the Area 5 RWMS and FY 2021 for the northern expansion area (BN, 2005b). The Area 3 RWMS was placed in cold standby in June 2006. The anticipated closure of the facility is FY 2009.

Interim CA revisions are scheduled because the requirement for CA revisions has been specified in the respective DASs for each of the facilities. The first scheduled Area 5 RWMS CA revision will incorporate the results of the Frenchman Flat Corrective Action Unit (CAU) Corrective Action Decision Document (CADD), currently scheduled for completion in FY 2009. Therefore, revision of the Area 5 RWMS CA is scheduled for FY 2010. The revised Area 3 RWMS CA will incorporate the results from the Yucca Flat CAU CADD, currently scheduled for completion in FY 2020. Therefore, a CA revision for the Area 3 RWMS is scheduled for FY 2021.

Special analyses are scheduled annually, which include all modeling and evaluations that directly or indirectly impact the results of the PAs and CAs and consequently lead NNSA/NSO to revise the effected documents. A special analysis is scheduled for FY 2007 to evaluate the performance of the Area 5 RWMS for the inadvertently disposed TRU waste in trench T04C, according to the performance objectives of Title 40 CFR 191. The support of the NTS RWAP, including the NTSWAC, will be an ongoing activity during the operational life of each facility. 


\subsection{QUALITY ASSURANCE}

All analytical and modeling work supporting the maintenance program activities of this plan will be performed in accordance with the quality assurance (QA) requirements of NSTec (the management and operations (M\&O) contractor of the NTS), and other contractors supporting the program. The QA programs of the $\mathrm{M} \& \mathrm{O}$ and subcontractors are established and implemented to fulfill the requirements of DOE Order 435.1, "Radioactive Waste Management” (DOE, 1999a); Title 10 CFR 830.122, “Quality Assurance” (CFR, 2006b); and DOE Order 414.1A, “Quality Assurance” (DOE, 1999e). QA for work performed by NSTec in general, and QA for the GoldSim model development and its applications are discussed below.

\subsection{Analysis and Modeling Quality Assurance}

Maintenance activities include development and use of various analytical tools and software. All maintenance work performed by NSTec complies with NSTec's Organizational Procedure OP-CENG.016, "Engineering Calculations” (NSTec, 2006). All analytical and modeling work is documented in an Engineering Analysis/Calculation package, checked and approved by the PA task manager. NSTec engineering maintains a suite of standard application programs, which are verified and documented. PA use of these programs does not require verification; however, PA use of any other software not in the list requires software verification documented in an engineering calculation package prior to its use.

\subsection{Quality Assurance for GoldSim Assessment Model Development}

Neptune and Company, Inc., is the developer of the PA models for the Area 3 and Area 5 RWMSs. These models are developed using the GoldSim systems analysis software, developed by the GoldSim Technology Group (http://www.goldsim.com/). The computer code has been verified and documented (McGrath and Beckham, 2001). The development of the Area 3 and Area 5 RWMSs using GoldSim is guided by Neptune and Company's Software Quality Assurance Plan for Development of GoldSim ${ }^{\circledR}$ Models Supporting Low-Level Radioactive Waste Disposal at the Nevada Test Site. The evolution of the GoldSim platform itself and the GoldSim models developed using it is controlled by the GoldSim versioning feature, which allows tracking of differences between versions. A written log of changes to the model, date, and programmer making the changes is maintained within a model note pane. Each GoldSim model is documented both internally (with notes and links in the GoldSim model itself) and externally (with a variety of external documents).

Neptune and Company makes releases of new model versions with all external documentation on a compact disc (CD) to the NNSA/NSO and NSTec for programmatic applications (e.g., Neptune and Company, Inc., 2002, 2003a, 2003b, and 2004). Before a new model version is used in programmatic applications, the model is subject to formal acceptability testing by NSTec and NNSA/NSO. The results of acceptability testing are documented in an acceptability review report (e.g., Crowe et al., 2004a; 2004b). 
The model may be modified by NSTec during the acceptability review or during specific applications. Each model application starts with the accepted version of the model. The modified model is versioned with an extension "mod" attached to the version number of the model modified. Modifications made during model application are documented in an Engineering Analysis/Calculation package, which includes an electronic copy of the modified code, and the NNSA/NSO is notified of the changes. These modifications, which are usually unique to a specific problem setting, may or may not be incorporated into the next version of the model to be released by Neptune and Company, Inc. Any modifications to the current accepted version of the model will need to be approved by NNSA/NSO.

\subsection{Quality Assurance for GoldSim Inventory Model Development}

Inventory models developed by NSTec, which provide the closure inventories for the Area 3 and Area 5 RWMS PA models, are documented in an Engineering Analysis/Calculation package in compliance with NSTec’s OP-CENG.016, “Engineering Calculations” (NSTec, 2006). Inventory model calculation packages must be approved and archived by NNSA/NSO.

As with the GoldSim PA models, the inventory models developed by NSTec for the Area 3 and Area 5 RWMSs are also controlled by the GoldSim versioning feature, which allows tracking of differences between versions. A written log of changes to the model, date, and programmer making the changes is maintained within a model note pane. In addition, a log of model output (inventory geometric means and geometric standard deviations) for each model version is maintained allowing tracking of changes. Inventory GoldSim models are verified by independent spreadsheet calculations. These calculations confirm that calculation of annual disposal rates, inventory revisions, and integration of disposal rates over time are correctly implemented.

\subsection{Quality Assurance for GoldSim Model Applications}

The GoldSim PA models exist as single GoldSim model files with the “.gsm” file extension. The model file for a specific application by NSTec contains all the code, input parameters, and model output, as well as the model documentation and links to external documentation files. Therefore, each model application requires that the GoldSim model file be saved with unique qualifiers attached to the file name for that particular application. A CD or DVD containing the model file is then attached to the engineering calculation package for that application.

The models are used routinely to support RWAP in waste profile approval process. All waste profiles submitted by generators must be evaluated by the PA health physicist, who signs off on the approval sheet. For profiles with significant inventories, the GoldSim PA model is run, with the proposed inventory added to the current disposed inventory in the model. The model file used to evaluate the profile and the calculation package is attached to the profile evaluation sheet. The entire package is then sent to NNSA/NSO for approval and archiving. 


\subsection{REFERENCES}

Black, P. K., K. J. Black, M. M. Hooten, L. P. Mathai, T. S. Stockton, and M. D. Neptune, 2001. Assessing the Probability of Inadvertent Human Intrusion at the Nevada Test Site Radioactive Waste, Management Sites - Volumes I and II. Argonne National Laboratory Contract No. W-31-109-Eng-38, U.S. Department of Energy, Nevada Operations Office, Las Vegas, NV.

BN (Bechtel Nevada), 1998. Nevada Test Site Routine Radiological Environmental Monitoring Plan. DOE/NV/1 1718--244. Bechtel Nevada, Las Vegas, NV.

- 2000. Composite Analysis for the Area 5 Radioactive Waste Management Site at the Nevada Test Site, Nye County, Nevada. DOE/NV--594. U.S. Department of Energy, Nevada Operations Office, Las Vegas, NV.

— 2001a. Addendum 1, Performance Assessment for the Area 5 Radioactive Waste Management Site at the Nevada Test Site, Nye County, Nevada; Reevaluation of the Inadvertent Human Intrusion Scenarios to Resolve the Disposal Authorization Statement Issues. DOE/NV/1 1718--176-ADD1. U.S. Department of Energy, National Nuclear Security Administration Nevada Operations Office, Las Vegas, NV.

-, 2001b. Addendum 1, Composite Analysis for the Area 5 Radioactive Waste Management Site at the Nevada Test Site, Nye County, Nevada; Reevaluation of the Chronic Inadvertent Human Intrusion Scenarios to Resolve the Disposal Authorization Statement Issues. DOE/NV--594-ADD1. U.S. Department of Energy, National Nuclear Security Administration Nevada Operations Office, Las Vegas, NV.

— 2001c. "Resolution of the Remaining Conditions of the Disposal Authorization Statement for the Nevada Test Site Area 3 Radioactive Waste Management Site.” Letter report from Michael B. Noland, BN; to E. Frank Di Sanza. Director, Waste Management Division, U.S. Department of Energy, National Nuclear Security Administration Nevada Operations Office. Bechtel Nevada, Las Vegas, NV.

_ 2002a. "NNSA/NV Environmental Management, Waste Management Division, LowLevel Waste Life Cycle Baseline.” U.S. Department of Energy, National Nuclear Security Administration Nevada Operations Office, Las Vegas, NV.

-, 2002b. “2001 Annual Summary Report for the Area 3 Radioactive Waste Management Site at the Nevada Test Site Nye County, Nevada.” U.S. Department of Energy, National Nuclear Security Administration Nevada Operations Office, Las Vegas, NV. 
-, 2003. "2002 Annual Summary Report for the Area 3 and Area 5 Radioactive Waste Management Sites at the Nevada Test Site Nye County, Nevada.” U.S. Department of Energy, National Nuclear Security Administration Nevada Operations Office, Las Vegas, NV.

-, 2004. “2003 Annual Summary Report for the Area 3 and Area 5 Radioactive Waste Management Sites at the Nevada Test Site Nye County, Nevada.” U.S. Department of Energy, National Nuclear Security Administration Nevada Operations Office, Las Vegas, NV.

, 2005a. "2004 Annual Summary Report for the Area 3 and Area 5 Radioactive Waste Management Sites at the Nevada Test Site Nye County, Nevada.” U.S. Department of Energy, National Nuclear Security Administration Nevada Operations Office, Las Vegas, NV.

, 2005b. Integrated Closure and Monitoring Plan for the Area 3 and Area 5 Radioactive Waste Management Sites at the Nevada Test Site. DOE/NV/11718-449-REV2. Bechtel Nevada, Las Vegas, NV.

-, 2006a. Addendum 2 to the Performance Assessment for the Area 5 Radioactive Waste Management Site at the Nevada Test Site, Nye County, Nevada: Update of Performance Assessment Methods and Results. DOE/NV/11718--1145. Bechtel Nevada, Las Vegas, NV. June 2006.

-, 2006b. "2005 Annual Summary Report for the Area 3 and Area 5 Radioactive Waste Management Sites at the Nevada Test Site Nye County, Nevada.” U.S. Department of Energy, National Nuclear Security Administration Nevada Operations Office, Las Vegas, NV.

Cochran, J. R., W. E. Beyeler, D. A. Brosseau, L. H. Brush, T. J. Brown, B. Crowe, S. H. Conrad, P. A. Davis, T. Ehrhorn, T. Feeney, B. Fogleman, D. P. Gallegos, R. Haaker, E. Kalinina, L. L. Price, D. P. Thomas, and S. Wirth, 2001. Compliance Assessment Document for the Transuranic Wastes in the Greater Confinement Disposal Boreholes at the Nevada Test Site. Volume 2. Performance Assessment Version 1.1. Sandia National Laboratories, Albuquerque, NM.

CFR (Code of Federal Regulations), 2006a. Title 40 CFR 191, July 1, 2006.

—_, 2006b. Title 10 CFR 830.122, “Quality Assurance.” January 1, 2006.

Crowe, B., V. Yucel, and G. Shott, 2004a. “Acceptability of the Area 5 Radioactive Waste Management Site Probabilistic Performance Assessment Model Version 3.0mod, Revision 1.” Memorandum to Jhon Carilli, U.S. Department of Energy, National Nuclear Security Administration Nevada Site Office. December 2004. 
Crowe, B., J. Tauxe, V. Yucel, and G. Shott, 2004b. “Acceptability of the Area 5 Radioactive Waste Management Site Probabilistic Performance Assessment Model Version 2.301.” Memorandum to Jhon Carilli, U.S. Department of Energy, National Nuclear Security Administration Nevada Site Office, June 2004.

DOE (U.S. Department of Energy), 1990. DOE Order 5400.1, “General Environmental Protection Program.” U.S. Department of Energy, Washington, D.C. June 29, 1990. , 1993. DOE Order 5400.5, "Radiation Protection of the Public and the Environment." U.S. Department of Energy, Washington, D.C. January 7, 1993.

— Management Complex Performance Assessment.” Letter, Stephen P. Cohan, Deputy Assistant Secretary for Waste Management. EM-35; to Leah Dever, Assistant Manager for Environmental Management, U.S. Department of Energy, Nevada Operations Office, Las Vegas, NV.

- 1996b. Final Environmental Impact Statement for the Nevada Test Site and Offsite Locations in the State Nevada. DOE/EIS 0243. U.S. Department of Energy, Nevada Operations Office, Las Vegas, NV. August 1996.

— 1998. Nevada Test Site Resource Management Plan. DOE/NV--518. U.S. Department of Energy, Nevada Operations Office, Las Vegas, NV.

— 1999a. DOE Order 435.1, “Radioactive Waste Management.” U.S. Department of Energy, Washington, D.C. July 9, 1999.

—, 1999b. DOE M 435.1-1, “A Radioactive Waste Management Manual.” U.S. Department of Energy, Washington, D.C. July 9, 1999.

—, 1999c. DOE G 435.1-1, “An Implementation Guide for Use with DOE M 435.1-1.” U.S. Department of Energy, Washington, D.C. July 9, 1999.

_ 1999d. DOE Order 435.1-3, "Maintenance Guide for U.S. Department of Energy LowLevel Waste Disposal Facility Performance Assessments and Composite Analyses.” U.S. Department of Energy, Washington, D.C. November 10, 1999.

, 1999e. DOE Order 414.1A, “Quality Assurance.” U.S. Department of Energy, Washington D.C. September 29, 1999.

—, 2001. Yucca Mountain Science and Engineering Report: Technical Information Supporting Site Recommendation Consideration. DOE/RW-0539. U.S. Department of Energy, Office of Civilian Radioactive Waste Management. 
Federal Register, 2000. “Nevada Test Site, NV; low-level waste and mixed low-level waste treatment and disposal,” 10061-10066 [FR Doc. 00-4439]. February 25, 2000.

FFACO (Federal Facility Agreement and Consent Order, as amended), 1996. Agreed to by the state of Nevada, the U.S. Department of Energy, and the U.S. Department of Defense. March 15, 1996.

Golder Associates, Inc., 2001. GoldSim Software. GoldSim Consulting Group, Golder Associates, Inc., Redmond, WA.

McGrath, T., and C. Beckham, 2001. "Verification Report for GoldSim Version 7.10.” GoldSim Consulting Group, Golder Associates, Inc., Redmond, WA.

Neptune and Company, Inc., 2002, Letter Report Area 5 GoldSim Model Version 1.1. Paul Black, Neptune and Company letter to Jhon Carilli, National Nuclear Security Administration Nevada Site Office. September 30, 2002.

—_, 2003a, Letter Report Area 5 GoldSim Model Version 2.0. Paul Black, Neptune and Company letter to Jhon Carilli, National Nuclear Security Administration Nevada Site Office. June 30, 2003.

— 2003b, Letter Report Area 5 GoldSim Model Version 2.1. Paul Black, Neptune and Company letter to Jhon Carilli, National Nuclear Security Administration Nevada Site Office. September 30, 2003.

— - 2004, Letter Report Area 5 GoldSim Model Version 3.0. Paul Black, Neptune and Company letter to Jhon Carilli, National Nuclear Security Administration Nevada Site Office. June 30, 2004.

NNSA/NSO (National Nuclear Security Administration Nevada Site Office), 2006a. Nevada Test Site Waste Acceptance Criteria. DOE/NV--325-Rev. 6-02. Las Vegas, NV. October 2006.

— Approval Process.” May 16, 2006.

NSTec (National Security Technologies, LLC), 2006. Organization Procedure OP-CENG.016, “Engineering Calculations.” July 1, 2006.

Shott, G. J., C. J. Muller, L. E. Barker, D. E. Cawlfield, F. T. Lindstrom, D. G. Linkenheil, M. J. Sully, L. McDowell-Boyer, and D. J. Thorne, 1995. Performance Assessment for the Area 5 Radioactive Waste Management Site at the Nevada Test Site, Nye County, Nevada. Revision 2.0. DOE/NV11432--196. Reynolds Electrical \& Engineering Co., Inc., Las Vegas, NV. 
Shott, G. J., V. Yucel, M. J. Sully, L. E. Barker, S. E. Rawlinson, and B A. Moore, 1997. Performance Assessment/Composite Analysis for the Area 3 Radioactive Waste Management Site at the Nevada Test Sites, Nye County Nevada. Revision 2.0. Bechtel Nevada, Las Vegas, NV.

Shott, G. J., L. E. Barker, S. E. Rawlinson, and M. J. Sully, 1998. Performance Assessment for the Area 5 Radioactive Waste Management Site at the Nevada Test Sites, Nye County, Nevada. DOE/NV/11718--176, Revision 2.1. Bechtel Nevada, Las Vegas, NV. 


\section{DISTRIBUTION}

J. T. Carilli

Waste Management Project

U.S. Department of Energy

National Nuclear Security Administration

Nevada Site Office, M/S 505

P.O. Box 98518

Las Vegas, NV 89193-8518

B. M. Crowe

Apogen Technologies, M/S 505

P.O. Box 98518

Las Vegas, NV 89193-8518

S. K. Krenzien

U.S. Department of Energy

National Nuclear Security Administration

Nevada Site Office, M/S 505

P.O. Box 98518

Las Vegas, NV 89193-8518

G. L. Pyles

Waste Management Project

U.S. Department of Energy

National Nuclear Security Administration

Nevada Site Office, M/S 505

P.O. Box 98518

Las Vegas, NV 89193-8518

U.S. Department of Energy

National Nuclear Security Administration

Nevada Site Office

Technical Library

P.O. Box 98518

Las Vegas, NV 89193-8518

U.S. Department of Energy

National Nuclear Security Administration

Nevada Site Office

Public Reading Facility

P.O. Box 98518

Las Vegas, NV 89193-8518
1 copy

1 copy

1 copy

1 copy

1 electronic copy

1 copy 
U.S. Department of Energy

1 electronic copy

Office of Scientific and Technical Information

P.O. Box 62

Oak Ridge, TN 37831-0062

R. B. Hudson

1 copy

National Security Technologies, LLC, M/S NLV094

1 electronic copy

P.O. Box 98521

Las Vegas, NV 89193-8521 